\title{
Crustal evolution history of Korean Peninsula in East Asia: The significance of Nd, Ce isotopic and REE data from the Korean Precambrian gneisses
}

\author{
Seung-Gu Lee, ${ }^{1} *$ Akimasa Masuda, ${ }^{1,2}$ Hiroshi Shimizu ${ }^{3}$ and Yong-Sun Song ${ }^{4}$ \\ ${ }^{1}$ Environmental Geology Division, Korea Institute of Geoscience and Mineral Resources, \\ 30 Kajeongdong, Yuseong, Taejeon 305-350, Korea \\ ${ }^{2}$ Department of Chemistry, University of Tokyo, Tokyo 113-0033, Japan \\ ${ }^{3}$ Department of Earth and Planetary Systems Science, Hiroshima University, \\ Higashi-Hiroshima 739-8526, Japan \\ ${ }^{4}$ Department of Environmental Geoscience, Pukyong National University, Pusan 608-737, Korea
}

(Received May 29, 2000; Accepted April 10, 2001)

\begin{abstract}
The Precambrian basement of the Korean Peninsula, located at the east margin of Asian continent, consists of the Nangrim Massif, the Gyeonggi Massif and the Sobaegsan (Yeongnam) Massif. Two kinds of orthogneisses (biotite gneiss and granitic gneiss) from the central part of the Sobaegsan Massif show the particular difference in geochemical features suggesting the discrimination in formation history. The biotite gneisses give an Sm-Nd whole rock isochron age of $819 \pm 114 \mathrm{Ma}(2 \sigma)$ with $\varepsilon_{\mathrm{Nd}}(0.82 \mathrm{Ga})=-15$, and the granitic gneisses give an age of $1484 \pm 810 \mathrm{Ma}(2 \sigma)$ with $\varepsilon_{\mathrm{Nd}}(1.48 \mathrm{Ga})=+7$. The $\varepsilon_{\mathrm{Nd}}$ and $\varepsilon_{\mathrm{Ce}}$ values for the granitic gneisses show characteristics of highly depleted mantle material and those of the biotite gneisses show their sources having light-REE enriched continental-like feature. Chondrite-normalized REE patterns are also different. Biotite gneisses have less fractionated patterns with $(\mathrm{La} / \mathrm{Yb})_{\mathrm{N}}$ ratio of 10 16 and negative $\mathrm{Eu}$ anomalies, while granitic gneisses have fractionated patterns with $(\mathrm{La} / \mathrm{Yb})_{\mathrm{N}}$ ratio of 30 180 with no/or positive Eu anomalies. The Ce-Nd isotopic results obtained here indicate that the Sobaegsan biotite gneisses were derived from continental-like sources having light-REE enriched feature, while the Sobaegsan granitic gneisses were derived from MORB-like sources having light-REE-depleted feature. These isotopic and REE data are interpreted as recording LREE fractionation events associated with major episodes of crust formation in East Asia. And the comparison of the initial $\varepsilon_{\mathrm{Nd}}$ value of the Sobaegsan biotite gneiss at $0.82 \mathrm{Ga}$ with those of the Chinese and Japanese Precambrian rocks implies that the sources for the Sobaegsan biotite gneisses and these Chinese and Japanese rocks had common lightREE enriched pattern, e.g., ${ }^{147} \mathrm{Sm} /{ }^{144} \mathrm{Nd}$ ratio ranging from $0.09-0.13$. Furthermore, it suggests that these sources having light-REE enriched patterns were derived from depleted mantle at the late Archean.
\end{abstract}

\section{INTRODUCTION}

The Korean Peninsula located at the eastern margin of Asian continent (Fig. 1) consists of three Precambrian basement domains that show the difference in their source, formation history, petrography and metamorphism, that is, the Nangrim Massif, the Gyeonggi Massif and the Sobaegsan Massif (Na, 1987; Song and Lee, 1989). The link- age of Korean Peninsula to Sino-Korean (North China) and South China Craton is still controversial (Lee, 1987; Cluzel et al., 1991; Lan et al., 1995; Ree et al., 1996; Kwon et al., 1997; Qiu et al., 2000).

The basement of Korean peninsula has been traditionally regarded as a part of the Sino-Korean Craton (Lee, 1987). However, the recent discovery of rare Archean basement rocks in the

*Corresponding author (e-mail: sgl@kigam.re.kr) 


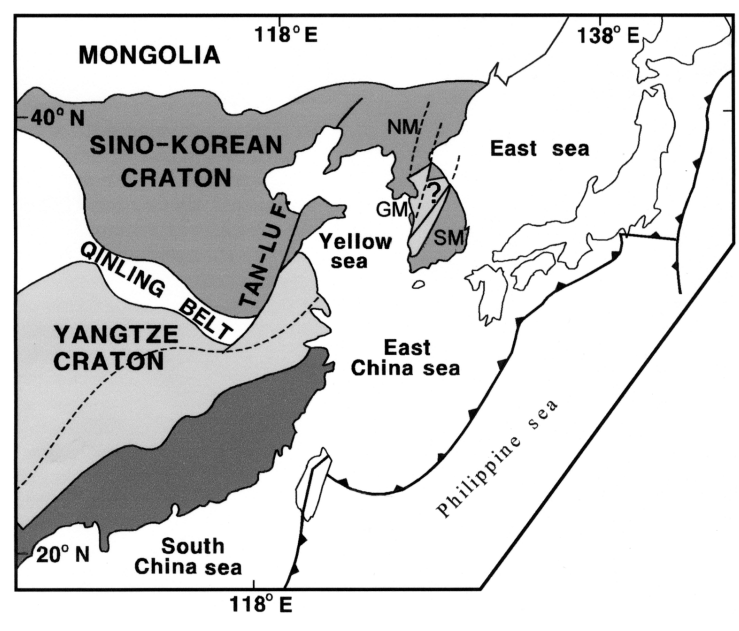

Fig. 1. General sketch-map of east Asia. The main cratonic blocks are stippled (after Cluzel et al., 1991). NM: Nangrim Massif, GM: Gyeonggi Massif, SM: Sobaegsan Massif.

South China block suggests also the possibility of correlation between South Korea and south China (Lan et al., 1995; Qiu et al., 2000). Lan et al. (1995) suggested the possibility of the presence of Archean crust in the Korean Peninsula. In addition, based on the range of $\mathrm{T}_{\mathrm{DM}}$ model age, they also suggested that the southern part of Korean Peninsula (South Korea) might be correlated with the South China Craton. Further the results of recent studies also have raised a possibility that the middle part of the Korean Peninsula might be a part of the South China Craton (Ree et al., 1996; Kwon et al., 1997; Qiu et al., 2000). On the contrary, Cluzel et al. (1991) suggested that the southern part of the Korean Peninsula had been a part of the Sino-Korean Craton before the early Triassic. Based on petrography and $\mathrm{Rb}-\mathrm{Sr}$ isochron age data, Adachi and Suzuki (1993) suggested that the Precambrian gneissic clasts in the Kamiaso conglomerate, Japan, could be derived from the eastern Korean Peninsula (Sobaegsan Massif). Adachi (1973) and Shibata and Adachi (1974) suggested that the gneissic clasts in the Kamiaso conglomerate found in central Japan were derived from a part of the Precambrian continent in East Asia. In addition, Adachi and Suzuki (1993), judg- ing from the nearly identical $\mathrm{Rb}-\mathrm{Sr}$ age and petrographical similarity between gneisses from the two areas, suggested as provenance of the Kamiaso gneissic clasts the Samcheok area in the eastern part of the Youngnam Massif (Sobaegsan Massif), south Korea. Contrary to this, based on initial $\mathrm{Nd}$ and $\mathrm{Ce}$ isotopic data of the orthogneisses from the Kamiaso conglomerate, central Japan, Shimizu et al. (1996) argued that the Samcheok gneisses of the Sobaegsan Massif, South Korea and the Kamiaso orthogneiss clasts were derived from different sources. Lee et al. (1992) suggested also the possibility that some Precambrian orthogneisses from Korea had evolved from protoliths that had similar geochemical properties to the Precambrian orthogneisses in Japan and northern China. Such different opinions for the formation history between Korean Peninsula and Japan Precambrian basement mean that the Precambrian basement of Korean Peninsula plays a key role to clarify the crustal evolution history in East Asia.

Two kinds of orthogneisses from the middle part of South Korea show some distinct features in $\mathrm{Nd}$, Ce isotope systematics and REE geochemistry. The purpose of this paper is to provide another geochemical evidence to clarify the relationship between China continent and Korean Peninsula, in East Asia crustal formation history. In this paper, based on the $\mathrm{Nd}-\mathrm{Ce}$ isotopic systematics and REE geochemistry, we discuss the significance that the geochemical difference between two kinds of the Sobaegsan Precambrian orthogneisses give in East-Asia crustal evolution history.

\section{Geology of Sobaegsan MASSIF AND SAMPLE DESCRIPTION}

The Sobaegsan Massif is one of the Precambrian basements in South Korea together with Gyeonggi Massif (Fig. 2(a)). Both massifs are similar in their constituent rocks and structure. The Sobaegsan Massif is mainly composed of Precambrian orthogneiss and metasediments intruded by Mesozoic granites. The metamorphic 


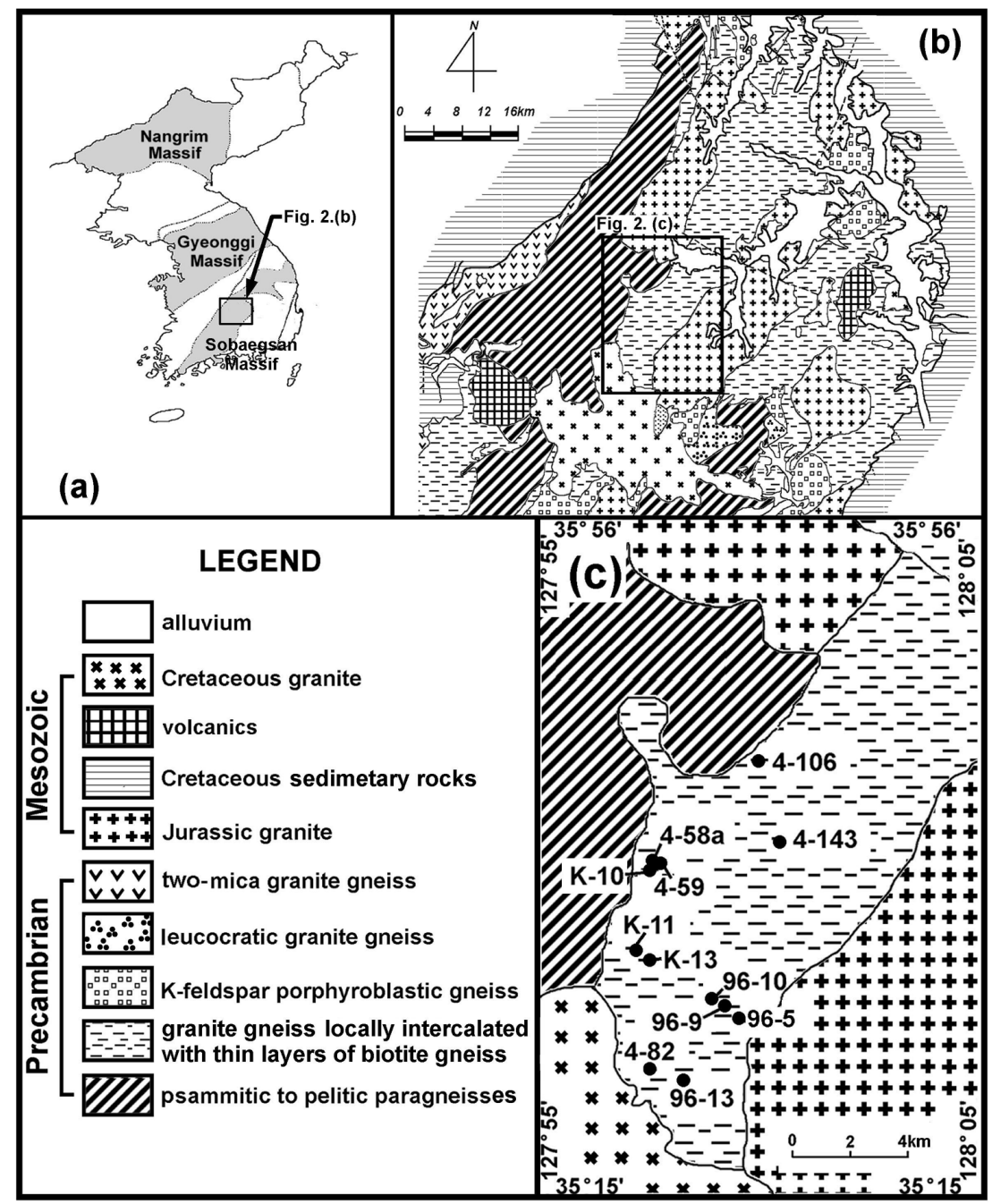

Fig. 2. (a) Index map of Precambrian tectonic units in Korea adapted from Um and Chun (1984). (b) Geological map of central Sobaegsan Massif in Korea. (c) Sample location map of the study area.

rocks correspond mostly to the low pressure facies series, with the amphibolite facies in the series being predominant. They were also suffered from polymetamorphism and retrograde metamorphism from upper amphibolite facies to greenschist facies (Na, 1987).

The granite gneiss studied in this paper occurs at the middle part of the Sobaegsan Massif and locates at $35^{\circ} 15^{\prime} \mathrm{N}-35^{\circ} 56^{\prime} \mathrm{N}$ and $127^{\circ} 55^{\prime} \mathrm{E}-$ $128^{\circ} 05^{\prime} \mathrm{E}$ (Fig. 2(b)). This gneiss is divided into the granitic gneiss and the biotite gneiss on the basis of mineral assemblage and texture. The biotite gneiss occurs with the width of a few to tens meters. In some places, the biotite gneiss shows characteristics of xenolith or resite. In general, it is difficult to distinguish the relationship between the biotite gneiss and the granitic gneiss on a regional scale.

In order to compare major element composition, REE abundances and $\mathrm{Nd}, \mathrm{Ce}$ isotopic systematics, we selected nine samples of the biotite gneiss and six samples of the granitic gneiss (Fig. 2(c)). In occurrence, the granitic gneiss is leucocratic, and shows a well-developed foliation, 
and migmatitic structures such as vein and schollen type. It is composed of quartz, plagioclase, K-feldspar and biotite. Secondary muscovite and chlorite are also observed. Compared to the granitic gneiss, the biotite gneiss is dark colored and is typically banded. It comprises biotite, quartz, plagiocalse and K-feldspar, with minor hornblende, clinopyroxene and orthopyroxene.

\section{Analytical Procedures}

Whole rock samples were crushed into grains of several millimeters with a jaw crusher and about 20-50 g of the grains collected were pulverized in an agate mill. Major element compositions were determined with a SHIMAZU VF-320A X-ray fluorescence spectrometer. In order to analyze REE abundance and $\mathrm{Nd}$ and Ce isotope compositions, about $0.5-1 \mathrm{~g}$ of the powdered sample was completely decomposed by $\mathrm{HF}$ and $\mathrm{HClO}_{4}$ using a teflon beaker. For isotope dilution method, REE were separated from the major elements by an AG $50 \mathrm{~W}-\mathrm{X} 8$ resin column in $\mathrm{HCl}$ media. The pure $\mathrm{Nd}$ and $\mathrm{Ce}$ fractions for isotope analysis were separately isolated form the decomposed solution using an AG 50W-X8 resin column with $\alpha$-hydroxyisobutric acid.

REE abundances were determined by isotope dilution using a JEOL JMS-05RB mass spectrometer at University of Tokyo, Japan and a VG-PQ ICP-MS at Korea Basic Science Institute

Table 1(a). Major element compositions (\%) and rare earth element, Sr, Rb and Ba abundances (ppm) for biotite gneiss from the Sobaegsan Massif, Korea

\begin{tabular}{|c|c|c|c|c|c|c|c|c|c|}
\hline & $\mathrm{K}-11$ & K-13 & $4-58 \mathrm{a}$ & $4-59$ & 3303 & $96-5-2$ & 96-9-1 & $96-9-2$ & $96-10-2$ \\
\hline $\mathrm{SiO}_{2}$ & 63.8 & 63.3 & 61.0 & 53.5 & 66.2 & 59.6 & 64.6 & 59.6 & 65.2 \\
\hline $\mathrm{TiO}_{2}$ & 0.73 & 0.93 & 1.16 & 2.79 & 0.59 & 1.36 & 0.53 & 1.36 & 1.05 \\
\hline $\mathrm{Al}_{2} \mathrm{O}_{3}$ & 14.5 & 15.8 & 16.2 & 18.1 & 16.7 & 14.9 & 18.8 & 14.9 & 14.3 \\
\hline $\mathrm{Fe}_{2} \mathrm{O}_{3}^{\text {total }}$ & 8.28 & 8.14 & 9.35 & 10.7 & 5.19 & 10.4 & 2.85 & 10.4 & 7.34 \\
\hline $\mathrm{MnO}$ & 0.09 & 0.08 & 0.09 & 0.14 & 0.04 & 0.14 & 0.03 & 0.14 & 0.07 \\
\hline $\mathrm{MgO}$ & 2.54 & 2.26 & 2.54 & 3.65 & 1.42 & 2.90 & 0.93 & 2.90 & 2.18 \\
\hline $\mathrm{CaO}$ & 3.74 & 3.50 & 3.74 & 6.24 & 3.38 & 4.69 & 4.75 & 4.69 & 3.75 \\
\hline $\mathrm{Na}_{2} \mathrm{O}$ & 3.06 & 2.78 & 3.06 & 3.20 & 3.13 & 2.57 & 5.15 & 2.57 & 2.60 \\
\hline $\mathrm{K}_{2} \mathrm{O}$ & 2.75 & 3.04 & 2.75 & 1.65 & 3.16 & 1.96 & 1.34 & 1.96 & 2.45 \\
\hline $\mathrm{P}_{2} \mathrm{O}_{5}$ & 0.08 & 0.12 & 0.08 & 0.12 & 0.20 & 0.17 & 0.07 & 0.17 & 0.29 \\
\hline Total & 99.57 & 99.95 & 99.97 & 100.09 & 100.01 & 98.69 & 99.05 & 98.69 & 99.23 \\
\hline $\mathrm{La}$ & 18.2 & 87.1 & 9.72 & 67.4 & 34.9 & 67.6 & 54.1 & 44.1 & 39.9 \\
\hline $\mathrm{Ce}$ & 36.8 & 174.9 & 180.1 & 125.1 & 73.1 & 126.1 & 102.5 & 87.8 & 79.9 \\
\hline $\mathrm{Nd}$ & 15.4 & 70.8 & 71.4 & 50.1 & 31.1 & 52.7 & 42.0 & 40.5 & 40.0 \\
\hline $\mathrm{Sm}$ & 3.30 & 12.1 & 11.2 & 7.66 & 5.76 & 8.47 & 7.23 & 8.31 & 8.35 \\
\hline $\mathrm{Eu}$ & 0.90 & 2.32 & 2.10 & 1.45 & 1.41 & 1.79 & 1.92 & 1.57 & 1.75 \\
\hline Gd & 3.14 & 9.74 & 8.11 & 5.34 & 4.93 & 7.78 & 6.54 & 8.76 & 8.29 \\
\hline $\mathrm{Tb}$ & - & - & - & - & - & 1.04 & 0.86 & 1.42 & 1.01 \\
\hline Dy & 2.56 & 7.87 & 5.01 & 3.48 & 4.14 & 6.42 & 4.93 & 9.41 & 6.70 \\
\hline Ho & - & - & - & - & - & 1.24 & 0.81 & 1.89 & 1.27 \\
\hline $\mathrm{Er}$ & 1.27 & 4.30 & 2.84 & 1.86 & 1.99 & 3.71 & 2.06 & 5.99 & 3.56 \\
\hline $\mathrm{Tm}$ & - & - & - & - & - & 0.53 & 0.22 & 0.91 & 0.48 \\
\hline $\mathrm{Yb}$ & 1.15 & 3.76 & 2.40 & 1.66 & 1.46 & 3.61 & 1.33 & 5.73 & 3.35 \\
\hline $\mathrm{Lu}$ & 0.17 & 0.56 & 0.35 & 0.25 & 0.21 & 0.56 & 0.16 & 0.84 & 0.52 \\
\hline$(\mathrm{La} / \mathrm{Yb})_{\mathrm{N}}{ }^{1)}$ & 10.4 & 15.2 & 26.6 & 26.7 & 15.7 & 12.3 & 26.8 & 5.07 & 7.85 \\
\hline $\mathrm{Eu}^{* 2}$ & 0.85 & 0.64 & 0.65 & 0.61 & 0.80 & 0.67 & 0.84 & 0.56 & 0.64 \\
\hline
\end{tabular}

${ }^{1)}$ The REE abundance in the Leedey chondrite (Masuda et al., 1973; Masuda, 1975) are employed as the normalizing values.

${ }^{2)} E u^{*}$ is defined as the ratio of observed Eu abundance to that which would fall on Sm-Nd join in chondrite-normalized REE patterns.

$K-11, K-13,4-58 a, 4-59$ and 3303 were analyzed by IDMS, and 96-5-2, 96-9-1, 96-9-2 and 96-10-2 were analyzed by ICP-MS. 
(KBSI), Korea. The isotopic composition of Ce was measured with a VG54-38 double focusing mass spectrometer at University of Tokyo. The measured isotopic ratio of $\mathrm{Ce}$ was normalized against ${ }^{136} \mathrm{Ce} /{ }^{142} \mathrm{Ce}=0.01688$. The ${ }^{138} \mathrm{Ce} /{ }^{142} \mathrm{Ce}$ ratio of Johnson Matthey $\mathrm{CeO}_{2}$ (JMC304) was $0.0225799 \pm 0.0000018\left(2 \sigma_{\mathrm{m}}\right)$ on 42 measurements. $\mathrm{Nd}$ isotopic ratios were measured at two laboratories, one on a VG 354 mass spectrometer at the University of Tokyo and the other on a VG 54-30 mass spectrometer at the Korea Basic Science Institute (KBSI). The experimental procedures for each mass spectrometer were those described by Lee et al. (1992), and Cheong and
Chang (1997), respectively. The ${ }^{143} \mathrm{Nd} /{ }^{144} \mathrm{Nd}$ ratios for the La Jolla Nd standard are $0.511826 \pm$ $0.000003\left(2 \sigma_{\mathrm{m}}\right)$ on 10 measurements at VG 354, and $0.511849 \pm 0.000004\left(2 \sigma_{\mathrm{m}}\right)$ on 16 measurements at VG 54-30 mass spectrometer.

\section{RESULTS}

\section{Major element and REE geochemistry}

Major element compositions and REE abundance for the Sobaegsan samples are presented in Table 1. The results are plotted on the An-Ab-Or diagram (Fig. 3, O'Connor, 1965). The chemical compositions of the biotite gneiss and the granitic

Table 1(b). Major element compositions (\%) and rare earth element, $\mathrm{Sr}, \mathrm{Rb}$ and Ba abundances (ppm) for granitic gneiss from the Sobaegsan Massif, Korea

\begin{tabular}{|c|c|c|c|c|c|c|}
\hline & $96-10-1$ & $96-13-1$ & $4-82$ & 4-106 & $4-143$ & K-10 \\
\hline $\mathrm{SiO}_{2}$ & 65.8 & 69.2 & 65.1 & 58.7 & 70.7 & 70.5 \\
\hline $\mathrm{TiO}_{2}$ & 0.48 & 0.42 & 0.88 & 1.18 & 0.33 & 0.34 \\
\hline $\mathrm{Al}_{2} \mathrm{O}_{3}$ & 17.7 & 16.0 & 16.3 & 21.6 & 16.3 & 16.2 \\
\hline $\mathrm{Fe}_{2} \mathrm{O}_{3}$ total & 3.05 & 2.39 & 3.80 & 3.81 & 2.11 & 2.26 \\
\hline $\mathrm{MnO}$ & 0.03 & 0.03 & 0.03 & 0.03 & 0.03 & 0.03 \\
\hline $\mathrm{MgO}$ & 0.86 & 0.64 & 1.33 & 1.55 & 0.50 & 0.56 \\
\hline $\mathrm{CaO}$ & 4.14 & 2.86 & 3.76 & 5.97 & 2.95 & 2.92 \\
\hline $\mathrm{Na}_{2} \mathrm{O}$ & 4.42 & 3.79 & 4.24 & 4.87 & 3.71 & 4.00 \\
\hline $\mathrm{K}_{2} \mathrm{O}$ & 2.34 & 3.51 & 1.83 & 1.97 & 3.30 & 3.10 \\
\hline $\mathrm{P}_{2} \mathrm{O}_{5}$ & 0.14 & 0.12 & 0.19 & 0.31 & 0.10 & 0.09 \\
\hline Total & 98.96 & 98.96 & 97.46 & 99.94 & 100.02 & 100.0 \\
\hline $\mathrm{La}$ & 51.8 & 36.1 & 54.9 & 18.3 & 67.7 & 46.3 \\
\hline $\mathrm{Ce}$ & 91.3 & 64.7 & 100.3 & 35.1 & 119.6 & 83.7 \\
\hline Pr & 9.53 & 7.18 & - & - & - & - \\
\hline $\mathrm{Nd}$ & 31.5 & 24.9 & 31.0 & 15.0 & 40.0 & 26.5 \\
\hline $\mathrm{Sm}$ & 4.16 & 3.95 & 4.09 & 2.40 & 5.40 & 3.64 \\
\hline $\mathrm{Eu}$ & 1.23 & 1.09 & 1.09 & 1.76 & 3.18 & 1.03 \\
\hline $\mathrm{Gd}$ & 2.85 & 3.25 & 2.44 & 1.77 & 1.41 & 2.20 \\
\hline $\mathrm{Tb}$ & 0.26 & 0.36 & - & - & - & - \\
\hline Dy & 1.48 & 1.98 & 1.34 & 1.03 & 1.18 & 1.23 \\
\hline Ho & 0.20 & 0.30 & - & - & - & - \\
\hline $\mathrm{Er}$ & 0.69 & 0.94 & 0.74 & 0.48 & 0.40 & 0.55 \\
\hline $\mathrm{Tm}$ & - & 0.69 & - & - & - & - \\
\hline $\mathrm{Yb}$ & 0.60 & 0.05 & 0.64 & 0.39 & 0.25 & 0.40 \\
\hline $\mathrm{Lu}$ & - & - & 0.095 & 0.056 & 0.037 & 0.053 \\
\hline$(\mathrm{La} / \mathrm{Yb})_{\mathrm{N}}{ }^{1)}$ & 56.9 & 44.0 & 56.4 & 31.0 & 179 & 76.2 \\
\hline $\mathrm{Eu}^{* 2)}$ & 1.04 & 0.92 & 0.98 & 2.04 & 2.80 & 1.04 \\
\hline
\end{tabular}

\footnotetext{
${ }^{1)}$ The REE abundances in the Leedey chondrite (Masuda et al., 1973; Masuda, 1975) are employed as the normalizing values. ${ }^{2)} E u^{*}$ is defined as the ratio of observed Eu abundance to that which would fall on Sm-Nd join in chondrite-normalized REE patterns.

4-82, 4-106, 4-143 and K-10 were analyzed by IDMS, and 96-10-1 and 96-13-1 were analyzed by ICP-MS.
} 


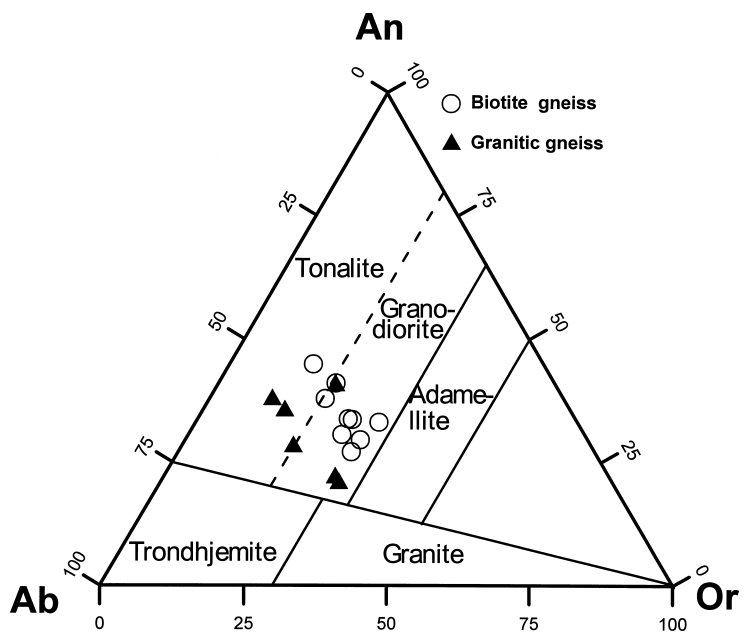

Fig. 3. Plot of normative feldspars showing classification of acidic rocks after O'Connor (1965).

gneiss correspond to granodiorite and tonalite, respectively. Compared to the biotite gneiss, the granitic gneiss shows higher $\mathrm{SiO}_{2}, \mathrm{Na}_{2} \mathrm{O}$ content and lower total $\mathrm{Fe}_{2} \mathrm{O}_{3}, \mathrm{MgO}$. Chondrite-normalized REE patterns (Masuda et al., 1973) are shown in Figs. 4(a) (b) and (c). Although all of the Sobaegsan samples show light-REE enriched patterns, there are differences between the biotite gneiss and the granitic gneiss. The granitic gneiss has more fractionated patterns with $(\mathrm{La} / \mathrm{Yb})_{\mathrm{N}}$ ratios between 30 and 180, and distinctly positive Eu or no anomalies (Figs. 4(a) and (b)), whereas the biotite gneiss has less fractionated patterns with $(\mathrm{La} / \mathrm{Yb})_{\mathrm{N}}$ ratios between 10 and 16 , and negative Eu anomalies (Fig. 4(c)). The REE pattern of which is composed two rectilinear lines with no Eu anomaly is also observed for the granitic gneiss (Fig. 4(a)).

\section{Isotopic data for Sm-Nd and La-Ce}

$\mathrm{Sm}-\mathrm{Nd}$ isotopic compositions are given in Table $2 .{ }^{143} \mathrm{Nd} /{ }^{144} \mathrm{Nd}$ values of the biotite gneiss are 0.511274 to 0.511621 , while those of granitic gneiss are 0.511803 to 0.512053 . The depleted mantle model ages $\left(\mathrm{T}_{\mathrm{DM}}\right)$ of the two gneisses are also distinctly different from each other. $\mathrm{T}_{\mathrm{DM}}$ ages of the biotite gneiss are $2.33 \mathrm{Ga}$ to $3.97 \mathrm{Ga}$ and show more or less scatter; the $\mathrm{Nd}$ model ages of
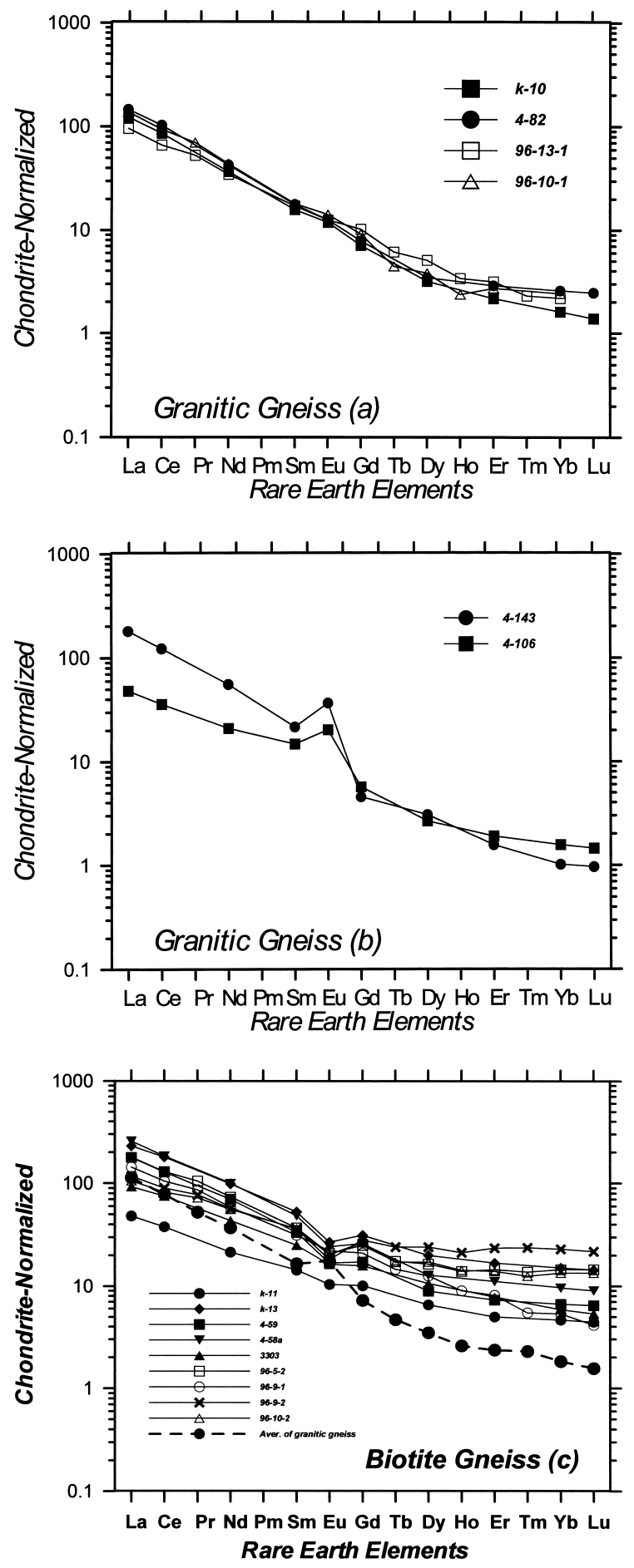

Fig. 4. Chondrite-normalizd REE pattern of granitic gneisses ((a) and (b)) and biotite gneisses (c) from Sobaegsan Massif, south Korea (solid symbol: IDMS, open symbol: ICP-MS). The REE abundances in the Leedey chondrite (Masuda et al., 1973; Masuda, 1975) are employed as the normalizing values. 
Table 2. Sm-Nd and La-Ce isotopic data for orthogneisses from the Sobaegsan Massif, Korea

\begin{tabular}{ccccccccc}
\hline & ${ }^{147} \mathrm{Sm} /{ }^{144} \mathrm{Nd}$ & ${ }^{143} \mathrm{Nd} /{ }^{144} \mathrm{Nd}^{*}$ & $\varepsilon_{\mathrm{Nd}}(0)$ & $\mathrm{T}_{\mathrm{DM}}(\mathrm{Ga})$ & ${ }^{138} \mathrm{La} /{ }^{142} \mathrm{Ce}$ & ${ }^{138} \mathrm{Ce} /{ }^{142} \mathrm{Ce}{ }^{*}$ & $\varepsilon_{\mathrm{Ce}}(0)$ & $\varepsilon_{\mathrm{Ce}}(\mathrm{T})$ \\
\hline $\begin{array}{l}\text { Biotite gneisses } \\
\mathrm{K}-11^{1)}\end{array}$ & 0.1299 & $0.511537 \pm 9$ & $-21.5 \pm 0.2$ & 2.92 & 0.00405 & $0.0225782 \pm 16$ & $+2.7 \pm 0.7$ & $+1.3 \pm 0.7$ \\
$\mathrm{~K}-13^{1)}$ & 0.1035 & $0.511363 \pm 9$ & $-24.9 \pm 0.2$ & 2.46 & 0.00405 & $0.0225783 \pm 20$ & $+2.7 \pm 0.9$ & $+1.3 \pm 0.9$ \\
$4-58^{1)}$ & 0.0948 & $0.511304 \pm 8$ & $-26.0 \pm 0.2$ & 2.36 & 0.00441 & $0.0225730 \pm 14$ & $+0.3 \pm 0.7$ & $-1.5 \pm 0.7$ \\
$4-59^{1)}$ & 0.0915 & $0.511274 \pm 8$ & $-26.6 \pm 0.2$ & 2.33 & 0.00440 & $0.0225821 \pm 12$ & $+4.4 \pm 0.5$ & $+2.5 \pm 0.5$ \\
$3303^{1)}$ & 0.1119 & $0.511411 \pm 8$ & $-23.9 \pm 0.2$ & 2.59 & 0.00390 & $0.0225773 \pm 14$ & $+4.9 \pm 0.6$ & $+1.1 \pm 0.6$ \\
$96-5-2^{2)}$ & 0.1028 & $0.511415 \pm 8$ & $-23.9 \pm 0.2$ & 2.37 & & & \\
$96-9-1^{2)}$ & 0.1086 & $0.511497 \pm 6$ & $-22.3 \pm 0.1$ & 2.39 & & & \\
$96-9-2^{2)}$ & 0.1253 & $0.511456 \pm 6$ & $-23.0 \pm 0.1$ & 2.90 & & & & \\
$96-10-2^{2)}$ & 0.1555 & $0.511621 \pm 8$ & $-19.1 \pm 0.2$ & 3.97 & & & \\
Granitic gneisses & & & & & & & \\
$\mathrm{K}-10^{1)}$ & 0.0829 & $0.511872 \pm 7$ & $-14.9 \pm 0.1$ & 1.49 & 0.00452 & $0.0225748 \pm 14$ & $+1.2 \pm 0.6$ & $-1.6 \pm 0.6$ \\
$4-82^{1)}$ & 0.0796 & $0.511803 \pm 8$ & $-16.3 \pm 0.2$ & 1.53 & 0.00447 & $0.0225733 \pm 14$ & $+0.5 \pm 0.8$ & $-2.2 \pm 0.8$ \\
$4-106^{1)}$ & 0.0963 & $0.511995 \pm 10$ & $-12.5 \pm 0.2$ & 1.50 & 0.00426 & $0.0225800 \pm 13$ & $+3.5 \pm 0.6$ & $+1.2 \pm 0.6$ \\
$4-143^{1)}$ & 0.0817 & $0.511896 \pm 9$ & $-14.5 \pm 0.2$ & 1.45 & 0.00463 & $0.0225784 \pm 30$ & $+2.7 \pm 1.3$ & $-0.2 \pm 1.3$ \\
$96-10-1^{2)}$ & 0.0763 & $0.511859 \pm 8$ & $-15.2 \pm 0.2$ & 1.43 & & & & \\
$96-13-1^{2)}$ & 0.0972 & $0.512053 \pm 8$ & $-11.4 \pm 0.2$ & 1.43 & & & & \\
\hline
\end{tabular}

Errors are $2 \sigma_{m}$ and correspond to the last significant figures. Ce and Nd isotopic ratios listed here corrected values relative to ${ }^{138} \mathrm{Ce}^{142} \mathrm{Ce}=0.0225762$ for JMC304 standard (Makishima et al., 1987) and ${ }^{143} \mathrm{Nd} /{ }^{144} \mathrm{Nd}=0.511858$ for La Jolla Nd standard (Lugmair et al., 1983).

${ }^{1)}$ The Nd isotope data were already reported from Lee et al. (1992).

${ }^{2)}$ New data of this study.

$T_{D M}=1 / \lambda \times \ln \left\{1+\left[\left({ }^{143} \mathrm{Nd} /{ }^{144} \mathrm{Nd}\right)_{\text {sample }}-0.51315\right] /\left[\left({ }^{147} \mathrm{Sm} /{ }^{144} \mathrm{Nd}\right)_{\text {sample }}-0.2137\right]\right\}, \lambda_{\text {Sm }}=6.54 \times 10^{-12}$

$\varepsilon(T)=\left[R_{m}(T) / R_{C H U R}(T)-1\right] \times 10^{4}$, where $R_{m}(T)$ and $R_{C H U R}(T)$ refer to the isotopic ratios of ${ }^{143} \mathrm{Nd} / /^{144} \mathrm{Nd}$ or ${ }^{138} \mathrm{Ce} /{ }^{142} \mathrm{Ce}$ for a sample $(m)$ and $C H U R$.

$\left({ }^{138} \mathrm{Ce}^{142} \mathrm{Ce}\right)_{\mathrm{CHUR}}(0)=0.0225722$ and $\left({ }^{138} \mathrm{La} /{ }^{142} \mathrm{Ce}\right)_{\mathrm{CHUR}}(0)=0.003089$ (Shimizu et al., 1984, 1988).

$\left({ }^{143} N d /{ }^{144} N d\right)_{C H U R}(0)=0.512638$ and $\left({ }^{147} \mathrm{Sm} /{ }^{144} \mathrm{Nd}\right)_{\text {CHUR }}(0)=0.1966$ (Wasserburg et al., 1981).

up to $3.97 \mathrm{Ga}$ (sample 96-10-2) provide evidence of older reworked crustal material in Korean Peninsula. But $\mathrm{T}_{\mathrm{DM}}$ ages of the granitic gneiss, 1.43 Ga to $1.53 \mathrm{Ga}$, show a much narrow range. Such a difference in $\mathrm{Nd}$ model age from two gneisses strongly suggests the possibility that they had originated from different source, respectively.

Lee et al. (1992) reported $c a .1 .70 \mathrm{Ga}$ and 1.05 $\mathrm{Ga}$ of $\mathrm{Sm}-\mathrm{Nd}$ error-chron ages for four granitic gneisses and three biotite gneisses, respectively. In this paper, we recalculated them with addition of new Nd isotopic data to previous samples (Table 2: 96-5-2, 96-9-1, 96-9-2, 96-10-2 for biotite gneiss; 96-5-1, 96-10-1, 96-13-1). Isotopic data were fitted to isochrons following the regression method of York (1969). As a result, we obtained ages of $819 \pm 114 \mathrm{Ma}(2 \sigma)$ with $\varepsilon_{\mathrm{Nd}}=-15.3$ for the biotite gneiss, and $1484 \pm 810 \mathrm{Ma}(2 \sigma)$ with $\varepsilon_{\mathrm{Nd}}=+7$ for the granitic gneiss (Fig. 5). Even though the $\mathrm{Sm}-\mathrm{Nd}$ isochron age of $1.48 \mathrm{Ga}$ from the granitic gneiss has the large error range of \pm 0.8 $\mathrm{Ga}$, it corresponds well with $\mathrm{T}_{\mathrm{DM}}$ ages in Table 2 .

La-Ce isotopic data are also given in Table 2. $\varepsilon_{\mathrm{Ce}}(0)$ values for the biotite gneiss show ranges from +0.3 to +4.9 , while those of the granitic gneiss show ranges of -2.7 to +3.5 . $\varepsilon_{\mathrm{Ce}}(\mathrm{T})$ were also calculated based on $\mathrm{Sm}-\mathrm{Nd}$ isochron ages. $\varepsilon_{\mathrm{Ce}}(0.82 \mathrm{Ga})$ values of the biotite gneiss are range of -1.5 to +2.5 , while $\varepsilon_{\mathrm{Ce}}(1.48 \mathrm{Ga})$ values of the granitic gneiss are range of -2.2 to +1.2 .

\section{DiscUSSIONS}

\section{Major and REE geochemistry}

Even though the major element composition of biotite gneiss and granitic gneiss falls in the same compositional fields of granodiorite and tonalite, they divide into two distinct groups on the An-Ab-Or diagram (Fig. 3). Especially, the granitic gneiss shows a characteristic of Na-rich 


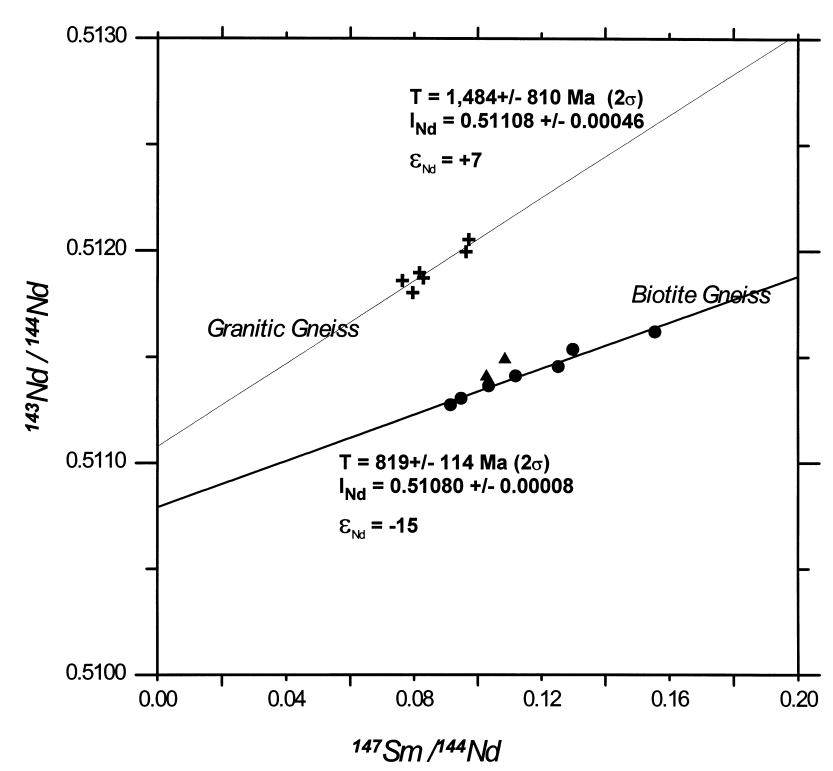

Fig. 5. ${ }^{143} \mathrm{Nd} /{ }^{144} \mathrm{Nd}-{ }^{147} \mathrm{Sm} /{ }^{144} \mathrm{Nd}$ plot for the biotite gneisses and granitic gneisses (note: the triangles in biotite gneisses are not included into isochron following the regression method of York (1969)).

granite. The difference between the granitic gneiss and the biotite gneiss can also be observed from chondrite-normalized REE pattern diagram (Fig. 4). As shown in Figs. 4(a) and (b), the granitic gneiss shows REE patterns with positive and/or no Eu anomalies, LREE-enriched and HREE-depleted. Such REE patterns of the granitic gneiss are similar to those of typical Archean tonalite and trondhjemite, and Na-granodiorite derived from a primitive source (Taylor and McLennan, 1995). In contrast, the biotite gneiss is characterized by nearly uniform REE patterns with LREE-enriched and negative Eu anomalies, which are similar to those of post-Archean shale (Taylor and McLennan, 1985). In geology section of this paper, we said that it is difficult to distinguish the relationship between the granitic gneiss and the biotite gneiss in the area studied. In Fig. 4(c), we compared the REE pattern of granitic gneiss (dashed line), which is average value, to those of biotite gneiss. They are different from Eu anomaly, HREE abundance and gradient. Since REEs are highly insoluble and immobile, it is well known that the pattern of REEs often remain unchanged during metamorphism in most cases. It is diffi- cult to think that that such a difference had been made from magmatism or metamorphism simply. Therefore, the sharp difference in the REE pattern between the granitic gneiss and the biotite gneiss can be also understood to reveal that these gneisses should have originated from different source materials.

Model ages and initial isotopic ratios and sources

The Sm-Nd system is ideal for investigating an evolution history of chemical reservoirs within the earth such as a net enrichment of $\mathrm{Nd}$ in the crust and a complementary depletion in the mantle because it reflects the history of the generation and destruction of continental crust (DePaolo, 1988; Jacobsen, 1988; Bowring and Housh, 1995). In general, the $\mathrm{Nd}$ model age such as $\mathrm{T}_{\mathrm{DM}}$ suggests an upper limit for the formation age of the respective crustal segments although it generally cannot be assigned to geologic processes (Arndt and Goldstein, 1987). As stated in the result section, depleted mantle model ages (Table 2) between 1.43 and $1.53 \mathrm{Ga}$ from Sobaegsan granitic gneiss shows good correspondence with the $1.48 \pm 0.81 \mathrm{Ga} \mathrm{Sm}-\mathrm{Nd}$ isochron age. And the de- 
pleted mantle model ages of biotite gneiss are included into the ranges of $2.33 \mathrm{Ga}$ to $3.97 \mathrm{Ga}$ (Table 2), and much older than $0.82 \mathrm{Ga}$ of the $\mathrm{Sm}-\mathrm{Nd}$ systematic age (Fig. 5). The wide range of model ages from biotite gneiss may be due to the complex history of its formation process. The $0.82 \mathrm{Ga}$ of Sm-Nd systematic age for biotite gneiss suggests that $\mathrm{Nd}$ isotopic system was significantly reset during the high-grade metamorphism. The relatively large chronological uncertainties concerned are also considered as attributing to partial re-equilibration during the high-grade metamorphism. Furthermore, the $1.48 \pm 0.81 \mathrm{Ga}$ Sm$\mathrm{Nd}$ isochron age of the granitic gneiss possibly represents the crustal formation age of a magmatic suite that was extracted from a highly depleted mantle source.

Radiogenic isotope systematics involving REE have made major contributions to understanding of crustal evolution processes (DePaolo, 1988; Lipin and McKay, 1989). It is well known that $\varepsilon_{\mathrm{Nd}}(\mathrm{T})$ value depends on the product of time and the magnitude of $\mathrm{Sm} / \mathrm{Nd}$ chemical fractionation parameters against CHUR. The recalculated ages and initial $\varepsilon_{\mathrm{Nd}}$ values for the Sobaegsan samples are plotted in Fig. 6 . The points for $\varepsilon_{\mathrm{Nd}}(\mathrm{T})$ values of Chinese Precambrian rocks (solid circles: Jahn and Zhang, 1984; Xuan et al., 1986; Jahn et al., 1987, 1988; Jahn and Ernst, 1990; Li et al., 1990; Wang et al., 1990; Sun et al., 1992, 1993; Hu et al., 1991; Rämö et al., 1995; Bai and Dai, 1996) with that (open circle) for Kamiaso gneiss clasts from Japan (Shimizu et al., 1996) are also shown in Fig. 6. In the $\varepsilon_{\mathrm{Nd}}$ evolution diagram, a $\varepsilon_{\mathrm{Nd}}$ line is traced back in time from $\varepsilon_{\mathrm{Nd}}(0.82 \mathrm{Ga})$ point for the Sobaegsan biotite gneisses (S1), employing the observed ${ }^{147} \mathrm{Sm} /{ }^{144} \mathrm{Nd}$ values of $0.09-0.15$ for these samples (line A) up to the $\varepsilon_{\mathrm{Nd}}=c a .+6$ with $2.6 \mathrm{Ga}$. Figure 6 also shows that the Nd evolution line for the Sobaegsan biotite gneiss, Chinese and Kamiaso gneisses intersect the Nd evolution lines for depleted-mantle (DM), around 2.6 $\mathrm{Ga}$ at the late Archean or early Proterozoic. This suggests that the source of biotite gneiss had been derived from depleted mantle at the late Archean and early Proterozoic. Our data suggests strongly

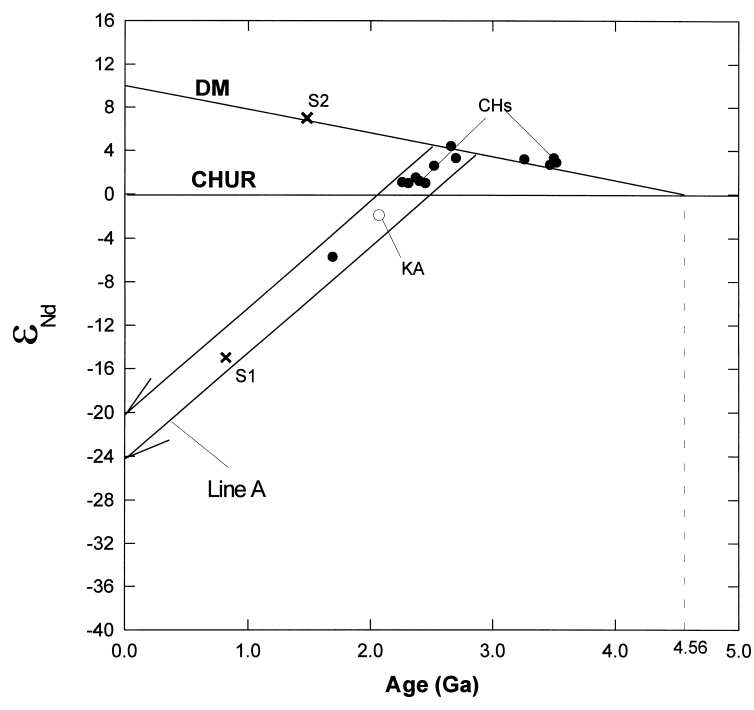

Fig. 6. $\varepsilon_{N d}$ vs. age diagram showing Nd isotopic composition of biotite gneiss (S1) and granitic gneiss (S2), orthogneiss and amphibolites of north-China Craton, Japan. Depleted-mantle line are drawn with $\varepsilon_{N d}(0)=$ +9 to 11 and $\varepsilon_{N d}(4.56 \mathrm{Ga})=0$. The $\varepsilon_{N d}(0)$ values are typical of MORB (Hawkesworth and van Calsteren, 1984; Liew and McCulloch, 1985). CHUR = chondritic uniform reservoir. Solid circles (CHs) are data of Chinese samples rocks (Jahn and Zhang, 1984; Xuan et al., 1986; Jahn et al., 1987, 1988; Jahn and Ernst, 1990; Li et al., 1990; Wang et al., 1990; Sun et al., 1992, 1993; Hu et al., 1991; Rämö et al., 1995; Bai and Dai, 1996). The point of Japanese sample (open circle) is from Shimizu et al. (1996).

that the source of the basement for the Sobaegsan Massif presumably had a close relationship with that of Kamiaso, central Japan in its formation history.

Even though the Sm-Nd age of granitic gneiss is more or less uncertain, the high positive $\varepsilon_{\mathrm{Nd}}$ value indicates that the source for granitic gneiss (S2) was derived from highly depleted mantle material with little or no contamination from old crustal material (e.g., biotite gneisses $\mathrm{S} 1$ in the same area). The high initial $\varepsilon_{\mathrm{Nd}}$ value (+7 at 1.48 $\mathrm{Ga}$ ) of granitic gneiss appears to fall on the DM line, whereas granitoid rocks reported until now (Allègre and Ben Othman, 1980; Hamilton et al., 1980; Taylor and McLennan, 1985) fall below 
CHUR line. Xuan et al. (1986) suggested that the geochemistry of the early Archean mantle in east Asia may have been similar to that of the modern upper mantle with severe depletion in respect to magmaphile elements. Our results, along with those obtained by Jahn and Ernst (1990), also support their argument. Sivell and McCulloch (1991) reported that Hart Range meta-igneous complex of central Australia was derived from a highly depleted mantle source with initial $\mathrm{Nd}$ isotope ratios of +6.9 to +8.2 at $1.8 \mathrm{Ga}$. The obtained high initial $\varepsilon_{\mathrm{Nd}}$ value for the Sobaegsan granitic gneisses $\left(\varepsilon_{\mathrm{Nd}}=+7\right.$ at $\left.1.48 \mathrm{Ga}\right)$ is essentially comparable to that of the Hart Range meta-igneous complex and reflects the presence of mantle source having a similar chemical characteristic beneath Korean Peninsula. Pearce (1996) suggested that granites from ocean ridges or volcanic arcs usually have characteristics that indicate depleted mantle sources. Such a fact indicates that the global tectonic environment that formed source magma of granitic gneiss in Korean Peninsula at $1.48 \mathrm{Ga}$ ago might be like ocean ridge or volcanic arc.

\section{Ce-Nd systematics and its implications}

Because both La and Ce belong to the rare earth element group, as is the case for the Sm-Nd system, the combined application of both systems is a promising tool for isotope geochemistry. Tanaka and Masuda (1982) applied the ${ }^{138} \mathrm{La}-{ }^{138} \mathrm{Ce}$ geochronometer to the Bushveld gabbro. Since then, the La-Ce system coupled with Sm-Nd system offers us an efficient tool to argue about LREE evolution (Tanaka et al., 1987; Shimizu et al., 1984, 1988, 1990a, 1990b, 1996). In order to compare the $\mathrm{Sm}-\mathrm{Nd}$ and $\mathrm{La}-\mathrm{Ce}$ isotope systematics for biotite and granitic gneisses, the data are shown in a $\varepsilon_{\mathrm{Ce}} \varepsilon_{\mathrm{Nd}}$ diagram (Fig. 7). In Fig. 7, open symbols mean the present value of $\varepsilon_{\mathrm{Ce}}$ and $\varepsilon_{\mathrm{Nd}}$, while solid symbols refer to the initial values of them. Even though the ages of Sm-Nd systematic from two gneisses show the relatively large uncertainty, in order to calculate the initial value of $\varepsilon_{\mathrm{Ce}}$, we applied to $1.48 \mathrm{Ga}$ and $0.82 \mathrm{Ga}$ for granitic gneiss and biotite gneiss, respectively. As a result, the

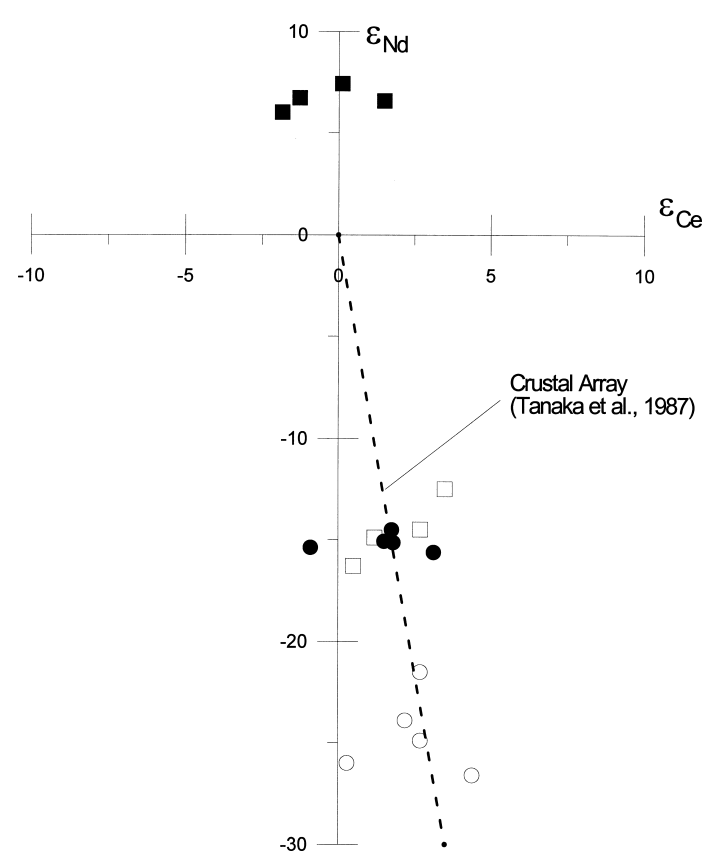

Fig. 7. $\varepsilon_{C e}-\varepsilon_{N d}$ diagram of the present isotopic compositions $(\varepsilon(0)$, open symbols) and initial isotopic compositions $(\varepsilon(T)$, solid symbol) at $0.82 \mathrm{Ga}$ (biotite gneisses, circle), 1.48 Ga (granitic gneisses, rectangle), respectively. A broken lines is drawn for old crustal rocks and indicates $\varepsilon_{C e}=-0.112 \varepsilon_{N d}$ (Tanaka et al., 1987).

$\varepsilon_{\mathrm{Ce}}{ }^{-} \varepsilon_{\mathrm{Nd}}$ diagram shows that the present isotopic data for biotite gneiss mainly fall on a line for typical crustal rocks, that is "crustal array", as defined by Tanaka et al. (1987), and that the corresponding data for granitic gneiss generally appear rather scattered. In addition, initial $\varepsilon_{\mathrm{Ce}}(0.82 \mathrm{Ga})$ and initial $\varepsilon_{\mathrm{Nd}}(0.82 \mathrm{Ga})$ values for the biotite gneiss are in +1.1 to 2.5 and -11.3 to -11.8 respectively, except one (4-58a) falling also on the crustal array. The $\varepsilon_{\mathrm{Ce}}(0.82 \mathrm{Ga})$ and $\varepsilon_{\mathrm{Nd}}(0.82 \mathrm{Ga})$ data for biotite gneiss support continental-like light-REE enriched characteristics for their sources. The $\varepsilon_{\mathrm{Ce}}$ and $\varepsilon_{\mathrm{Nd}}$ values calculated for the reference age $(1.48 \mathrm{Ga})$ of the granitic gneiss range from -2.2 to +1.2 and from +7.0 to +8.4 , respectively, suggesting chiefly light-REE depleted nature mainly for the source of the granitic gneisses. The points for the present and initial values of $\mathrm{Ce}$ isotopes from granitic gneisses show severe scattered dis- 
persion, which suggest also their origin different from Tanaka's old crustal array (1987). This $\varepsilon_{\mathrm{Ce}^{-}}$ $\varepsilon_{\mathrm{Nd}}$ diagram shows the clear difference in origin and formation history between biotite gneisses and granitic gneisses of Sobaegsan Massif, Korea. Further study may be necessary to achieve deeper interpretation of the relationship between $\varepsilon_{\mathrm{Ce}}$ and $\varepsilon_{\mathrm{Nd}}$ for reference ages of the granitic gneiss.

\section{CONCLUSION}

In conclusion, although the Sm-Nd ages obtained for the granitoid gneiss shows large uncertainties, $\mathrm{Nd}, \mathrm{Ce}$ isotopic data clearly suggest the different sources between two types of the Sobaegsan gneisses. The Ce-Nd isotopic results obtained here indicate that the Sobaegsan biotite gneiss originated from continental-like sources having light-REE enriched features, while the Sobaegsan granitic gneiss was from MORB-like sources having light-REE-depleted characters. In addition, comparison of the initial $\varepsilon_{\mathrm{Nd}}$ value of the Sobaegsan biotite gneiss at $0.82 \mathrm{Ga}$ with those of the Chinese and Japanese Precambrian rocks implies that source for the Sobaegsan biotite gneiss has commonly light-REE enriched pattern, e.g., ${ }^{147} \mathrm{Sm} /{ }^{144} \mathrm{Nd}$ ratio ranging from $0.09-0.13$. Furthermore, it is suggested that these sources having light-REE enriched patterns could be traced back to depleted mantle at the late Archean. Especially, the highly positive initial $\mathrm{Nd}$ value for granitic gneiss corresponds to the extension of the mantle in the Sino-Korean Craton. Such two phenomena suggest strongly that the source for the basement of Sobaegsan Massif, Korea, had close relationship with the Sino-Korean Craton rather than South China Craton.

Acknowledgments-This work was a part of a doctoral thesis of S-G. Lee and was supported mainly by a grant-in-aid for scientific research from the Ministry of Education, Science and Culture in Japan and partly Nulwon Research Fund in Korea to Dr. Y. S. Song. We thank Ms. Ho-Seon Lee for helping in drawing geologic map. This manuscript was improved by a critical reading by Prof. John Tarney (Leicester University, U.K.) and an anonymous reviewer.

\section{REFERENCES}

Adachi, M. (1973) Pelitic and quartzo-feldspathic gneisses in the Kamiaso conglomerate: a study of Precambrian geology in Japan and East Asia. J. Geol. Soc. Japan 79, 181-203.

Adachi, M. and Suzuki, K. (1993) Were Precambrian gneiss clasts in the Kamiaso conglomerate derived from the eastern Korea Peninsula? Bull. Nagoya Univ. Furukawa Museum 9, 25-45.

Allègre, C. J. and Ben Othman, D. (1980) Nd-Sr isotopic relationship in granitoid rocks and continental crust development: A chemical approach to orogenesis. Nature 286, 335-342.

Arndt, N. T. and Goldstein, S. L. (1987) Use and abuse of crust-formation ages. Geology 15, 893-895.

Bai, J. and Dai, F. (1996) The early Precambrian crustal evolution of China. J. Southeast Asian Earth Sci. 13, 205-214.

Bowring, S. A. and Housh, T. (1995) The Earth's early evolution. Science 269, 1535-1540.

Cheong, C. S. and Chang, H. W. (1997) Sr, Nd and Pb isotope systematics of granitic rocks in the central Ogcheon Belt, Korea. Geochem. J. 31, 17-36.

Cluzel, D., Lee, B.-J. and Cadet, J.-P. (1991) Indosinian dextral ductile fault system and synkinematic plutonism in the southwest of the Ogcheon belt (south Korea). Tectonophysics 194, 131-151.

DePaolo, D. J. (1988) Neodymium Isotope Geochemistry. Springer Verlag, Berlin-Heidelberg, $187 \mathrm{pp}$.

Hamilton, P. J., O'Nions, R. K. and Pankhurst, R. J. (1980) Isotopic evidence for the provenance of some Caledonian granites. Nature 287, 279-284.

Hawkesworth, C. J. and van Calsteren, P. W. C. (1984) Radiogenic isotopes-some geological applications. Rare Earth Element Geochemistry (Henderson, P., ed.), 375-421, Elsevier, Amsterdam.

Hu, A., Zhu, B., Mao, C., Zhu, N. and Huang, R. (1991) Geochronolgy of the Dahongshan Group. Chinese J. Geochem. 10/3, 195-203.

Jacobsen, S. B. (1988) Isotopic constraints on crustal growth and recycling rates. Earth Planet. Sci. Lett. 90, 315-329.

Jahn, B. M. and Ernst, W. G. (1990) Late Archean Sm$\mathrm{Nd}$ isochron age for mafic-ultramafic supracrustal amphibolites from the northeastern Sino-Korean Craton, China. Precambrian Res. 46, 295-306.

Jahn, B. M. and Zhang, Z. Q. (1984) Archean granulite gneisses from eastern Hebei Province, China: rare earth geochemistry and tectonic implications. Contr. Mineral. Petrol. 85, 224-243.

Jahn, B. M., Aurvay, B., Cornichet, J., Bai, Y. L., Shen, Q. H. and Liu, D. Y. (1987) 3.5 Ga old amphibolites 
from eastern Hebei Province, China: Field occurrence, petrography, Sm-Nd isochron age and REE geochemistry. Precambrian Res. 34, 311-346.

Jahn, B. M., Aurvay, B., Shen, Q. H., Liu, D. Y., Zhang, Z. Q., Dong, Y. J., Ye, X. J., Zhang, Q. Z., Cornichet, J. and Mace, J. (1988) Archean crustal evolution of the late Archean Taishan Complex, and evidence for juvenile crustal addition from long-term depleted mantle. Precambrian Res. 38, 381-403.

Kwon, S. T., Lee, E. Y. and Ree, J. H. (1997) Rb-Sr biotite ages from metamorphic rocks of the Gyeonggi Massif: Tectonic applications. J. Geol. Soc. Korea 33, 36-48.

Lan, C. Y., Lee, T., Zhou, X. H. and Kwon, S. T. (1995) Nd isotopic study of Precambrian basement of South Korea: evidence for early Archean crust. Geology 23, 249-252.

Lee, D. S. (1987) Geology of Korea. Geological Society of Korea (Lee, D. S., ed.), Kyohaksa Co., Seoul, $514 \mathrm{pp}$.

Lee, S. G., Shimizu, H., Masuda, A. and Song, Y. S. (1992) Crustal evolution of the Precambrian basement in the Korean Peninsula. J. Petrol. Soc. Korea 1, 124-131.

Li, S., Hart, S. R. and Wu, T. (1990) Rb-Sr and Sm-Nd isotopic dating of an Early Precambrian spilitekeratophyre sequence in the Wutaishan area, North China: Preliminary evidence for Nd-isotopic homogenization in the mafic and felsic lavas during lowgrade metamorphism. Precambrian Res. 47, 191203.

Li, Z. X., Zhang, L. and Powell, C. McA. (1995) South China in Rodinia: Part of the missing link between Australia-East Antarctica and Laurentia. Geology 23, 407-410.

Liew, T. C. and McCulloch, M. Y. (1985) Genesis of granitoid batholith of Peninsula Malaysia and implications for models of crustal evolution: evidence from a $\mathrm{Sm}-\mathrm{Nd}$ isotopic and $\mathrm{U}-\mathrm{Pb}$ zircon study. Geochim. Cosmochim. Acta 49, 587-600.

Lipin, B. R. and McKay, G. A. (1989) Geochemistry and mineralogy of rare earth elements. Reviews in Mineralogy 21, Mineralogical Society of America, 348 pp.

Lugmair, G. W., Shimamura, T., Lewis, R. S. and Anders, E. (1983) Samarium-146 in the early solar system: evidence from neodymium in the Allende meteorite. Science 222, 1015-1018.

Makishima, A., Shimizu, H. and Masuda, A. (1987) Precise measurement of cerium and lanthanum isotope ratios. Mass Spectro. 35, 64-72.

Masuda, A. (1975) Abundances of mono isotopic REE, consistent with the Leedey chondritic values. Geochem. J. 9, 183-184.
Masuda, A., Nakamura, N. and Tanaka, T. (1973) Fine structure of mutually normalized rare-earth patterns of chondrites. Geochim. Cosmochim. Acta 37, 1922.

Na, K. C. (1987) Precambrian supererathem. Geology of Korea (Lee, D. S., ed.), Kyohaksa, 514 pp.

O'Connor, J. T. (1965) A classification for quartz-rich igneous rocks based on feldspar ratio. U.S. Geol. Surv. Prof. Paper 525B, 79-84.

Pearce, J. (1996) Sources and settings of granitic rocks. Episodes 19/4, 120-125.

Qiu, Y. M., Gao, S., McNaughton, N., Groves, D. I. and Ling, W. (2000) First evidence of $>3.2$ Ga continental crust in the Yangtze craton of south China and its implications for Archean crustal evolution and Phanerozoic tectonics. Geology 28, 11-14.

Rämö, O. T., Haapala, I., Yu, J. H. and Fu, H. Q. (1995) 1700 Ma Shachang complex, northeast China: Proterozoic rapakivi granite not associated with Paleoproterozoic orogenic crust. Geology 23, 815818.

Ree, J. H., Cho, M., Kwon, S. T. and Nakamura, E. (1996) Possible eastward extension of Chinese collision belt in South Korea: Imjingang belt. Geology 24, 1071-1074.

Shibata, K. and Adachi, M. (1974) Rb-Sr whole-rock ages of Precambrian metamorphic rocks in the Kamiaso conglomerate from central Japan. Earth Planet. Sci. Lett. 21, 277-287.

Shimizu, H., Tanaka, T. and Masuda, A. (1984) Meteoritic ${ }^{138} \mathrm{Ce} /{ }^{142} \mathrm{Ce}$ ratio and its evolution. $\mathrm{Na}$ ture 307, 251-252.

Shimizu, H., Nakai, S., Tasaki, S., Masuda, A., Bridgwater, D., Nutman, A. P. and Baadsgaard, H. (1988) Geochemistry of Ce and Nd isotopes and REE abundances in the Amîtsoq gneisses, West Greenland. Earth Planet. Sci. Lett. 91, 159-169.

Shimizu, H., Amakawa, H., Sawatari, H. and Masuda, A. (1990a) Estimation of light rare earth element patterns in original sources for rocks from their $\mathrm{Ce}$ and $\mathrm{Nd}$ isotopic ratios. Mass. Spec. 38, 107-133.

Shimizu, H., Umemoto, A., Masuda, A. and Appel, P. W. U. (1990b) Source of iron-formations in the Archean Isua and Malene supracrustals, West Greenland: Evidence from $\mathrm{La}-\mathrm{Ce}$ and $\mathrm{Sm}-\mathrm{Nd}$ isotopic data and REE abundances. Geochim. Cosmochim. Acta 54, $1147-1154$.

Shimizu, H., Lee, S. G., Masuda, A. and Adachi, M. (1996) Geochemistry of $\mathrm{Nd}$ and Ce isotopes and REE abundances in Precambrian orthogneiss clasts from the Kamiaso conglomerate, central Japan. Geochem. J. 30, 57-69.

Sivell, W. J. and McCulloch, M. T. (1991) Neodymium isotopic evidence for ultra depleted mantle in the 
early Proterozoic. Nature 354, 384-387.

Song, Y. S. and Lee, S. M. (1989) Petrology of the Precambrian metamorphic rocks from the central Sobaegsan Massif, Korea. J. Geol. Soc. Korea 25, 451-468.

Sun, M., Armstrong, R. L. and Lambert, St. J. (1992) Petrochemistry and $\mathrm{Sr}, \mathrm{Pb}$ and $\mathrm{Nd}$ isotopic geochemistry of Early Precambrian rocks, Wutaishan and Taihangshan areas, China. Precambrian Res. 56, $1-31$.

Sun, M., Armstrong, R. L., Lambert, R. St. J., Jiang, C. and $\mathrm{Wu}$, J. (1993) Petrochemistry and $\mathrm{Sr}, \mathrm{Pb}$ and $\mathrm{Nd}$ isotopic geochemistry of the Paleoproterozoic Kuandian Complex, the eastern Liaoning Province, China. Precambrian Res. 62, 171-190.

Tanaka, T. and Masuda, A. (1982) The La-Ce geochronometer: a new dating method. Nature 300, 515-518.

Tanaka, T., Shimizu, H., Kawata, Y. and Masuda, A. (1987) Combined La-Ce and Sm-Nd isotope systematics in petrogenetic studies. Nature 327, 113-117.
Taylor, S. R. and McLennan, S. M. (1985) The Continental Crust: Its Composition and Evolution. Blackwell Scientic Publications, Oxford, 312 pp.

Um, S. H. and Chun, H. Y. (1984) Tectonic map of Korea, Korea Inst. Ener. Resour., One sheet.

Wang, K., Windley, B. F., Sills, J. D. and Yan, Y. (1990) The Archean gneiss complex in E. Hebei Province, North China: geochemistry and evolution. Precambrian Res. 48, 245-265.

Wasserburg, G. J., Jacobsen, S. B., Depaolo, D. J., McCulloch, M. T. and Went, T. (1981) Precise determination of $\mathrm{Sm} / \mathrm{Nd}$ ratios, $\mathrm{Sm}$ and Nd isotopic abundances in standard solutions. Geochim. Cosmochim. Acta 45, 2311-2323.

Xuan, H., Ziwei, Bi. and Depaolo, D. J. (1986) Sm-Nd isotope study of early Archean rocks, Qianan, Hebei Province, China. Geochim. Cosmochim. Acta 50, 625-631.

York, D. (1969) Least squares fitting of a straight line with correlated errors. Earth Planet. Sci. Lett. 5, 320 324. 